\title{
An Investigation into Senior High School Students' Psychological Quality and Its Relationship with Their English Performance
}

\author{
Wen $\operatorname{Jin}^{1} \&$ Yuewu $\operatorname{Lin}^{1}$ \\ ${ }^{1}$ Foreign Languages College, Jiangxi Normal University, China \\ Correspondence: Yuewu Lin, Foreign Languages College, Jiangxi Normal University, Yaohu Campus, 99 \\ Ziyang road, Nanchang, Jiangxi, 330022, China. E-mail: 1024610498@qq.com
}

Received: April 6, 2018 Accepted: May 8, 2018 Online Published: May 11, 2018

doi: 10.5539/elt.v11n6p23 URL: http://doi.org/10.5539/elt.v11n6p23

\begin{abstract}
The psychological quality is a stable, basic and derivative psychological character, and is a dynamic organization composed of four subs - systems of cognition, personality psychology, mental health and social adaptation. Foreign and domestic scholars have done plenty of researches on the relationship between the academic performance and several main sub-dimensions of psychological quality such as responsibility, methods, initiative and confidence. Based on the previous studies, the study aims to investigate the general situation of senior high school students' psychological quality; How does English performance correlate with psychological quality and its eleven dimensions; What is the difference between high-proficient English learners and the low-proficient English learners in terms of the psychological quality and its eleven dimensions? The results show that the middle high school students have a relatively positive psychological quality; there is a positive and strong correlation between psychological quality and English performance. As for its eleven dimensions, the results show that there is a positively and strongly correlation between English performance and initiative, self-confidence, responsibility, self-control, methods, independence and persistence. There is a correlation between English performance and monitoring, frustration endurance and independence, which is not as strong as the above dimensions. And there is no correlation between English performance and thinking ability and innovation; there exist significantly difference between high-proficient and low-proficient English students in psychological quality, initiative, self-confidence, responsibility, self-control, methods, persistence, monitoring and frustration endurance. However, no difference has been found between high-proficient and low-proficient English students in independence, thinking ability and innovation.
\end{abstract}

Keywords: psychological quality, English performance, senior high school students

\section{Introduction}

With the all-round development of quality education in China, the role of psychological quality education has become increasingly prominent. More and more people realize that in the quality education, psychological quality occupies the core status and important role. And it is not only the starting point but also the home to the all-round development of education. Nowadays, psychological quality education has not only become the focus of education and psychology in China, but also become the focal point of all levels of schools and even the whole society. In 1988, the ministry of education has issued a document called "Further Strengthening and Improving the Moral Education Work" and the paper indicates that we should give mental health education and guidance to different age levels of students through a variety of different methods to help students to improve the psychological quality, healthy personality, enhance the sense of frustration endurance and the ability to adapt to the environment. It can be seen that the cultivation of students' health psychological quality has become an important goal of school education and meanwhile a significant part of quality education.

As the core of quality education, psychological quality plays an important role in promoting quality education, which requires educators and educational researchers to systematically carry out psychological quality education and researches. This study, as an attempt to study the psychological quality education, on the one hand is an in-depth study of the psychological quality education, which is conducive to the systematic, progressive understanding of the characteristics of Chinese students' psychological quality, and it also enriches the theory of psychological quality research. One the other hand, many English teachers from middle schools reflect that plenty of students are not willing to learn English and the study on the relationship between students' 
psychological quality and their English academic performance, can make the English educators better understand how the psychological quality restrict and promote the students' learning ability and adaptation mechanism and consequently improve the English performance of middle school students.

\section{Literature Review}

\subsection{The Definitions of Psychological Quality}

As far as Kerbo (1981) is concerned, psychological quality, personal personality or characteristic, is the concrete expression of human in real life.

Epstein (1989) proposes that psychological quality is the individual ability, and it is the psychological character of the individual in his paper Constructive thinking: a broad coping variable with a specific component.

The researches on the psychological quality at home are much more. Therefore, many scholars have raised their opinions and given the explicit definitions in terms of the psychological quality.

Qian (1997) considers psychological quality was a holistic dynamic system which consists of three subsystems: intelligence quality, personality factors as well as physical and mental potential.

Wang (1999) deems that psychological quality is a dynamic synthesis including intelligence factors, nonintellectual factors, mental health and potential factors.

Lai (1999) thinks that psychological quality in learning process refers to the students in the learning process of cultural and scientific knowledge skills, combined tendency of mental activity and psychological development level.

Xing (2002) puts forward that the psychological quality refers to the ability of people's psychological activity, that is, the ability of people to cope, bear and adjust various psychological pressure, and mainly manifests in the people's emotion and the stability of their behavior .

The author thinks that the psychological quality is a comprehensive embodiment of character quality and psychological ability formed on the basis of genetic basis and under the influence of education and environment, which is formed on the basis of the education and the environment.

\subsection{The Development of the Psychological Quality}

Psychological quality is a native concept born under the background of quality education in our country. By examining at the literatures about psychological quality at home and abroad, the author finds that the psychological quality is the native concept which attracted more attention from Chinese scholars. Thus, the foreign scholars have relatively few articles on the psychological quality as a whole. Most foreign scholars have focused on the sub-dimensions of the psychological quality, such as motivation, learning strategies and so on. In contrast, in recent years, scholars in China have studied the psychological quality more comprehensively, and the research on psychological quality has developed fast in recent years.

Comprehensive analysis shows that the study of psychological quality in China has experienced the following five stages:

The first is the budding stage (before 1996), in which the study of psychological quality has just begun, the number of academic literature is 412 , accounting for $6.95 \%$ of the total literature.

The second stage is the acceptance stage (1996-2000), the most prominent feature of which is the rapid increase in the number of literature on psychological quality research, although it has only been five years. But the number of published papers has reached 1052. The most influential research result in this stage is Zhang Da's paper "several problems on the study of students' Psychological quality" published in 2000. Up to now, 302 references have been cited. This paper has played an important leading role in promoting the academic community to accept the basic theoretical problems of psychological quality.

The third stage is the identification stage (2001-2003). The most notable feature of this stage is that the research field of psychological quality has been widely accepted, the most influential achievement is the study of psychological quality and mental health of the university students in Beijing published in 2001, which is now cited 278 times. In 2002, Zhang Da published papers on strengthening mental health education in schools to train students to improve their psychological quality, which has been cited for 96 times. In 2003, Zhang Da published a paper on the psychological quality of the students, which has been cited for 79 times. The high citation rate of many articles suggests that the research results of psychological quality have been accepted by many researchers.

The fourth stage is the differentiation stage (2004-2010). The most obvious feature of this stage is that the academic circle is about the basic theoretical problems such as the concept of psychological quality, structural 
elements and so on.

The last stage is the integration stage (2011-present). This stage is marked by the systematic analysis of psychological quality research system, the deep analysis of the specimen relation of psychological quality and mental health, and the output of the results of the series integration research. The marking event in this stage is the strategic planning workshop of the Chinese people's psychological quality study held in Chongqing in July 2014, the first time from the height of the top-level design, the planning of the technical route of the psychological quality integration research on the cooperation mechanism.

\section{Methodology}

\subsection{Research Questions}

The present study attempts to find out the answer to the following questions:

(1) What is the general situation of senior high school students' psychological quality?

(2) How does English performance correlate with psychological quality and its eleven dimensions?

(3) What is the difference between high-proficient English learners and the low-proficient English learners in terms of the psychological quality and its eleven dimensions? And if there exist some differences, how these related to English performance?

\subsection{Participants}

The sample consists of 139 senior high school students coming from JinDezhen NO.2 middle school in JiangXi province. 139 students are composed of two grades. 59 students are from Grade 1 and 80 students are from Grade 2.

\subsection{Instruments}

The study will adopt the quantitative methodology by using the psychological quality questionnaire and English test to examine the psychological quality of the senior high school students and its relationship with English performance.

\subsubsection{Psychological Quality Questionnaire}

The author uses the questionnaire to do a quantitative methodology. The scale we use in this study is based on the scale made by Zhang and Feng (2000), which is the most authoritative scale related to psychological quality and will be adapted for senior high school students after appropriate adjustments.

According to the scale of Zhang and Feng (2000), psychological quality can be divided into three dimensions: cognition quality, individuality quality as well as adaptability quality. Based on these three major dimensions, it can be further divided into more detailed sub-dimensions. Cognition quality consists of three sub dimensions, they respectively are thinking ability, monitoring and innovation. Individuality quality contains six sub dimensions: independence, persist, compulsion, self-confidence, responsibility, initiative. Adaptability quality is composed of two sub dimensions: methods as well as frustration endurance. Those sub-dimensions will be tested in the adjusted scale.

There are 43 questions in this questionnaire. 1-5 test initiative, 6-9 test thinking ability, 10-13 test the confidence, 14-16 test the students' learning responsibility, 17-18 test the diligence of the learners, compulsion will be tested during 19-21, 22-25 test the monitoring, 26-29 test the frustration endurance, 30-35 test the methods, 36-39 test the independence,39-40 test the innovation and persist will be tested during 41-43. The marks of each item are scored from 1 point (strongly disagree) to 5 points (strongly agree).

\subsubsection{Students' English Exam}

In addition to the psychological quality's questionnaire, students' final English exam scores in the second semester will be taken as an indicator of their English performance. The total score is 150 .

\subsection{Data Collection and Analysis}

Data collected from the psychological quality and English test are analyzed by SPSS22.0

\section{Results and Discussion of the Research}

\subsection{The Descriptive Statistics of Senior School Students' Psychological Quality}

Table 1 reveals the results including the number of the questionnaire, the maximum, the minim, the sum, the means and the standard deviations of the overall scores and the different dimensions of students' psychological quality in middle high school. 
Table 1. The Descriptive statistics of senior school students' psychological quality

\begin{tabular}{lccclll}
\hline & $\mathrm{N}$ & $\mathrm{Max}$ & $\mathrm{Min}$ & Sum & Mean & Std. Deviation \\
\hline Overall Score & 139 & 4.72 & 2.33 & 504.88 & 3.6323 & .47317 \\
Initiative & 139 & 5.00 & 2.00 & 556.80 & 4.0058 & .62598 \\
Thinking Ability & 139 & 5.00 & 1.00 & 433.75 & 3.1205 & .72629 \\
Self-Confidence & 139 & 5.00 & 2.00 & 541.75 & 3.8975 & .86278 \\
Responsibility & 139 & 5.00 & 1.60 & 511.40 & 3.6791 & .71814 \\
Self-Control & 139 & 5.00 & 1.33 & 482.65 & 3.4723 & .83221 \\
Monitoring & 139 & 5.00 & 1.75 & 475.00 & 3.4173 & .68919 \\
FrustrationEndurance & 139 & 5.00 & 2.00 & 536.50 & 3.8597 & .72301 \\
Methods & 139 & 5.00 & 2.00 & 502.98 & 3.6186 & .64199 \\
Independence & 139 & 5.00 & 2.00 & 537.36 & 3.8659 & .67035 \\
Innovation & 139 & 5.00 & 1.50 & 435.50 & 3.1331 & .79985 \\
Persistence & 139 & 5.00 & 1.33 & 490.68 & 3.5301 & .81144 \\
\hline
\end{tabular}

Note: the overall cut-off score is 3 ; the subscale cut-off score is 3 .

From Table 1, we can find that the overall mean score of it is 3.6323, more than the cut-off score 3 , the lowest overall score is 2.33 , the highest is 4.72 , the standard deviation is .47317 . These statistics show that the senior high school students have a relatively positive psychological quality.

As for the eleven dimensions of the psychological quality, their mean scores sequence from the highest to the lowest are as follows: Initiative (4.0058), self-confidence (3.8975), independence (3.8659) frustration endurance (3.8597), responsibility (3.6791), methods (3.6186), persistence (3.5301), self-control (3.4723), monitoring (3.4173), thinking ability (3.1205) and innovation (3.1331).

We can see from the table that the average score for senior high school students' initiative (4.0058) is the only one of all subdimensions that has a score of more than four. This shows that the overall initiative of the senior high school students is very high. The subjects in this paper come from the two key classes of Senior one and Senior two so the students are very progressive and eager to acquire new knowledge.

In addition to the initiative, we can also find that the average score of self-confidence (3.8975) and independence (3.8659) is relatively high, because this part of the students belongs to key class student, they enter high school with excellent grades in the middle school. So they will be more confident in their study. Similarly, because of their excellent grades, they are relatively independent in their learning and thinking, and have more independent thinking about their study and problems.

From the table, we can also find that the scores of thinking ability (3.1205) and innovation (3.1331) are relatively low. In the process of English learning, memory knowledge is more than comprehension knowledge. Students in liberal arts classes tend to have weaker thinking abilities than others. In terms of innovation, in the context of exam-oriented education, students think more about how to get better grades in a short period of time. The new thinking of solving problems is relatively scarce, so the overall innovative level of students is lower than other psychological quality sub-factor level. 


\subsection{Correlation Between Psychological Quality and English Performance}

Table 2. The correlations among English performance and psychological quality and its eleven dimensions

\begin{tabular}{|c|c|c|}
\hline & & Senior School students' English Performance \\
\hline \multirow[t]{3}{*}{ Initiative } & Pearson Correlation & $.601 * *$ \\
\hline & Sig.(2-tailed) & .000 \\
\hline & $\mathrm{N}$ & 80 \\
\hline \multirow[t]{3}{*}{ Thinking Ability } & Pearson Correlation & -.189 \\
\hline & Sig.(2-tailed) & .093 \\
\hline & $\mathrm{N}$ & 80 \\
\hline \multirow[t]{3}{*}{ Self-Confidence } & Pearson Correlation & $.389^{* *}$ \\
\hline & Sig.(2-tailed) & .000 \\
\hline & $\mathrm{N}$ & 80 \\
\hline \multirow[t]{3}{*}{ Responsibility } & Pearson Correlation & $.533^{* *}$ \\
\hline & Sig.(2-tailed) & .000 \\
\hline & $\mathrm{N}$ & 80 \\
\hline \multirow[t]{3}{*}{ Self-Control } & Pearson Correlation & $.404 * *$ \\
\hline & Sig.(2-tailed) & .000 \\
\hline & $\mathrm{N}$ & 80 \\
\hline \multirow[t]{3}{*}{ Monitoring } & Pearson Correlation & $.280 *$ \\
\hline & Sig.(2-tailed) & .012 \\
\hline & $\mathrm{N}$ & 80 \\
\hline \multirow[t]{3}{*}{ Frustration Endurance } & Pearson Correlation & $.253^{*}$ \\
\hline & Sig.(2-tailed) & .024 \\
\hline & $\mathrm{N}$ & 80 \\
\hline \multirow[t]{3}{*}{ Methods } & Pearson Correlation & $.494 * *$ \\
\hline & Sig.(2-tailed) & .000 \\
\hline & $\mathrm{N}$ & 80 \\
\hline \multirow[t]{3}{*}{ Self-Confidence } & Pearson Correlation & $.389^{* *}$ \\
\hline & Sig.(2-tailed) & .000 \\
\hline & $\mathrm{N}$ & 80 \\
\hline \multirow[t]{3}{*}{ Independence } & Pearson Correlation & $.230 *$ \\
\hline & Sig.(2-tailed) & .041 \\
\hline & $\mathrm{N}$ & 80 \\
\hline \multirow[t]{3}{*}{ Innovation } & Pearson Correlation & .152 \\
\hline & Sig.(2-tailed) & .179 \\
\hline & $\mathrm{N}$ & 80 \\
\hline \multirow[t]{3}{*}{ Persistence } & Pearson Correlation & $.475^{* *}$ \\
\hline & Sig.(2-tailed) & .000 \\
\hline & $\mathrm{N}$ & 80 \\
\hline \multirow{3}{*}{$\begin{array}{l}\text { Overall scores } \\
\text { (Psychological Quality) }\end{array}$} & Pearson Correlation & $.530 * *$ \\
\hline & Sig.(2-tailed) & .000 \\
\hline & $\mathrm{N}$ & 80 \\
\hline
\end{tabular}

Table 2 shows us the results of the correlation among English performance and psychological quality and its 
eleven dimensions, including initiative, thinking ability, self-confidence, responsibility, self-control, monitoring, frustration endurance, methods, independence, innovation, persistence. From the table4.2, we can find that the there is a positively correlation between psychological quality and English performance $\left(r=.530^{* *}, p=0.000<.05\right)$, which suggests that the better students' English performance are, the higher their psychological quality overall scores are. Then the detail discussion of the correlation between English performance and eleven dimensions of the psychological quality will be elaborated as follows.

In terms of the Initiative, it indicates the high motivation of the learners, and table4.2 shows that the initiative is related to the English performance $(\mathrm{r}=.601 * *, \mathrm{p}=0.000<.05)$. This result corresponds to the research made by Samad et al. (2012) to some extent. He conducted a study among Iranian EFL college students on the correlation between motivation and language proficiency. And he divided the subjects into two groups: high achievers and low achievers and he found that there is a strong correlation between the integrative motivation and language proficiency. Initiative, in this study, refers to the high motivation of the learners. In other words, it means that high motivation can in some degree prompt the students to get better grades in English learning. As English instructors, being aware of the importance and significance of the cultivation of the initiative (high motivation) is the first thing that should be done.

Table 4.2 reveals that the self-confidence of the English learners is also positively correlated with their English performance $\left(\mathrm{r}=.389^{* *}, \mathrm{p}=0.000<.05\right)$ which shows that the better students' English performance are, the more they are confident. This result is similar to the result conducted by Christopher (2003). He studied the relationship among academic achievement, motivation and self-confidence among the average age 19 years old students. The result shows that self-confidence has a significant predictive effect on students' academic performance. Self-confidence is the conviction of your strength, the conviction that you can accomplish something and achieve the goals you are pursuing. When the students hold the belief that they can make it, they can complete the task much easier and thus they are more likely to make good achievements in learning. Thus, our teachers should place a premium on the cultivation of the students' self-confidence.

Responsibility, one of the dimensions of the psychological quality, is also strongly and positively correlated with the English performance $\left(\mathrm{r}=.533^{* *}, \mathrm{p}=0.000<.05\right)$ in Table 2. Busato $(2000)$ uses the correlation analysis and multiple regression analysis techniques and he examines the relationship between College Students' sense of responsibility and their academic achievement. The results show that there is a significant positive correlation between them. The research conducted by Busato further confirms the correlation between students' sense of responsibility and their English performance. When completing the learning tasks, the sense of responsibility makes students realize the importance and necessity of finishing the tasks on time. They will learn to be responsible for themselves. Therefore, responsibility indeed matters in learning and should be highly emphasized.

Self-control is that you try to do something even though you don't want to. And then you can do what you want to do. Roy L. Smith said that self-control is like a controlled flame, and it creates genius. From the table 2, we can also find that there is a strongly correlation between learners' self-control and English performance (.404**, $\mathrm{p}=0.000<.05$ ). The students we teach belongs to a particular stage where they can't manage them well. Under this situation, they often break their plan because of their laziness. Our instructors should focus our attention on fostering their self-control and help them overcome their indolence.

Table 2 shows us that the methods of the learners are positively correlated with their English performance (.494**, $\mathrm{p}=0.000<.05)$. And this result corresponds to the research conducted by Park (1997), Green and Oxford (1995), Oxford and Nyikos (1989). They all conducted their studies with Oxford's SILL questionnaire and agreed there were a positive linear relationship between language learning strategy (LLS) and L2 proficiency. Methods refers to whether a learner can appropriately and effectively select a learning method to help them improve their performance and in other words can also be regarded as learning strategy. A good strategy can help learners much effectively proceed their learning process. And they are novice in English learning, our teachers who has been learning English for so many years should lead them to find the learning methods which are more effective and more suitable for them.

There is no doubt that the Table 2 shows us that there is positively and strongly correlation between the persistence and English performance $\left(.475^{* *}, \mathrm{p}=0.000<.05\right)$. As the old saying goes, dripping through stone is not a day's work. Everything will be done if you keep going and keep doing. As a language learning, English can't be leant well in such a short time, you should accumulate every day. Our instructors should help our students adjust their mood when they can't make obvious progress in learning and at the same time lead them to hold the belief that as long as they persist in learning English, they will make headway and achieve their goal 
one day.

From the Table 2, we can also find that monitoring, frustration endurance as well as independence is also correlated with the English performance, but they are not as strong as the dimensions we listed above. Our teachers should also pay attention to those dimensions.

Apart from the dimensions which are correlated with the English performance, we should also pay attention to two dimensions whch are not related to the English performance. They respectively are thinking ability and innovation. English is more of a liberal arts subject, with memory of vocabulary and grammar required. Students' memory rather than logical thinking is needed more than science subjects. Therefore, there is no correlation between thinking and English achievement. Regarding to the English tests, English examination questions are generally conventional lexical grammatical memory and rarely involve innovative parts, so it is not surprising that there is no correlation between innovation and English achievement.

\subsection{Differences of High-Proficient English Students and Low-Proficient English Students in Psychological Quality and its Dimensions}

Table 3. Independent sample test

\begin{tabular}{|c|c|c|c|c|c|c|c|c|c|}
\hline & $\begin{array}{l}\text { Leven } \\
\text { Test } \\
\text { quality } \\
\text { Varian }\end{array}$ & $\begin{array}{l}\text { for } \\
\text { of } \\
\text { ces }\end{array}$ & t-test fo & Equality & of Means & & & & \\
\hline & $\mathrm{F}$ & Sig. & $\mathrm{t}$ & $\mathrm{df}$ & Sig.(2-tailed) & $\begin{array}{l}\text { Mean } \\
\text { Difference }\end{array}$ & $\begin{array}{l}\text { Std.Errot } \\
\text { Difference }\end{array}$ & $\begin{array}{l}95 \% \text { Co } \\
\text { Interval } \\
\text { Differen }\end{array}$ & $\begin{array}{l}\text { fidence } \\
\text { f the } \\
\text { e }\end{array}$ \\
\hline & & & & & & & & Lower & Upper \\
\hline Overall & 1.128 & .294 & 6.131 & 42 & .000 & .74004 & .12070 & .49645 & .98363 \\
\hline Score & & & 6.086 & 39.546 & .000 & .74004 & .12159 & .49421 & .98587 \\
\hline Initiative & 4.912 & .032 & $\begin{array}{l}5.065 \\
4.965\end{array}$ & $\begin{array}{l}42 \\
33.263\end{array}$ & $\begin{array}{l}.000 \\
.000\end{array}$ & $\begin{array}{l}.93954 \\
.93954\end{array}$ & $\begin{array}{l}.18548 \\
.18922\end{array}$ & $\begin{array}{l}.56523 \\
.55470\end{array}$ & $\begin{array}{l}1.3138 \\
1.3243\end{array}$ \\
\hline Thinking & .173 & .680 & -1.231 & 42 & .225 & -.22826 & .18550 & -.60621 & .14069 \\
\hline Ability & & & -1.223 & 39.948 & .229 & -.22826 & .18666 & -.60553 & .14901 \\
\hline Self- & 7.435 & .009 & 4.496 & 42 & .000 & 1.08489 & .24129 & .59795 & 1.5718 \\
\hline Confidence & & & 4.423 & 35.137 & .000 & 1.08489 & .24530 & .58696 & 1.5828 \\
\hline $\begin{array}{l}\text { Respon- } \\
\text { sibility }\end{array}$ & 5.507 & .030 & $\begin{array}{l}5.456 \\
5.368\end{array}$ & $\begin{array}{l}42 \\
35.260\end{array}$ & $\begin{array}{l}.000 \\
.000\end{array}$ & $\begin{array}{l}1.07371 \\
1.07371\end{array}$ & $\begin{array}{l}.19680 \\
.20003\end{array}$ & $\begin{array}{l}.67654 \\
.66772\end{array}$ & $\begin{array}{l}1.4708 \\
1.4796\end{array}$ \\
\hline Self-Control & .001 & .971 & $\begin{array}{l}4.386 \\
4.373\end{array}$ & $\begin{array}{l}42 \\
40.991\end{array}$ & $\begin{array}{l}.000 \\
.000\end{array}$ & $\begin{array}{l}.97031 \\
.97031\end{array}$ & $\begin{array}{l}.22121 \\
.22187\end{array}$ & $\begin{array}{l}.52388 \\
.52223\end{array}$ & $\begin{array}{l}1.4167 \\
1.4184\end{array}$ \\
\hline Monitoring & .386 & .538 & $\begin{array}{l}2.973 \\
2.944\end{array}$ & $\begin{array}{l}42 \\
38.456\end{array}$ & $\begin{array}{l}.005 \\
.005\end{array}$ & $\begin{array}{l}.57195 \\
.57195\end{array}$ & $\begin{array}{l}.19237 \\
.19482\end{array}$ & $\begin{array}{l}.18373 \\
.17880\end{array}$ & $\begin{array}{l}.96016 \\
.96509\end{array}$ \\
\hline Frust ration & .168 & .684 & 2.895 & 42 & .006 & .57971 & .20028 & .17554 & .98388 \\
\hline Endurance & & & 2.877 & 39.970 & .006 & .57971 & .20152 & .17241 & .98701 \\
\hline Methods & 3.956 & .053 & $\begin{array}{l}5.403 \\
5.325\end{array}$ & $\begin{array}{l}42 \\
36.168\end{array}$ & $\begin{array}{l}.000 \\
.000\end{array}$ & $\begin{array}{l}1.01482 \\
1.01482\end{array}$ & $\begin{array}{l}.18782 \\
.19058\end{array}$ & $\begin{array}{l}.63578 \\
.63837\end{array}$ & $\begin{array}{l}1.3938 \\
1.4012\end{array}$ \\
\hline Independence & .212 & .648 & 1.474 & 42 & .148 & .29306 & .19887 & -.10828 & .69441 \\
\hline Innovation & 1380 & 247 & $\begin{array}{l}1.472 \\
1463\end{array}$ & $\begin{array}{l}41.442 \\
42\end{array}$ & $\begin{array}{r}.149 \\
151\end{array}$ & $\begin{array}{r}.29306 \\
36542\end{array}$ & $\begin{array}{r}.19909 \\
24984\end{array}$ & $\begin{array}{l}-.10887 \\
-13877\end{array}$ & $\begin{array}{l}.69500 \\
86962\end{array}$ \\
\hline Persistence & & & 1.476 & 41.569 & .148 & .36542 & .24760 & -.13441 & .86526 \\
\hline
\end{tabular}




$\begin{array}{lllllllll}3.741 & .060 & 5.919 & 42 & .000 & 1.05176 & .17768 & .69319 & 1.4103 \\ & & 5.805 & 33.498 & .000 & 1.05176 & .18118 & .68336 & 1.4201\end{array}$

The author adopted the first 23 highest scores and last 21 lowest scores in English performance to analyze the difference between the high-proficient English learners and low-proficient learners in terms of the psychological quality and its eleven dimensions by using the SPSS22.0. The top 23 students in English score constitute the high-proficient group, and the last 21 students in English make up a low-proficient group.The above data has been presented on the Table 3 which bring out the conclusion that there is an apparent difference among high-proficient and low-proficient English learners in terms of the psychological quality $(t=6.131, p=0.000$, $0.000<.05)$, initiative $(\mathrm{t}=5.065, \mathrm{p}=0.000,0.000<.05)$, self-confidence $(\mathrm{t}=4.496, \mathrm{p}=0.000, \quad 0.000<.05)$, responsibility $(\mathrm{t}=5.456, \mathrm{p}=0.000,0.000<.05)$, self-control $(\mathrm{t}=4.386, \mathrm{p}=0.000,0.000<.05)$, methods $(\mathrm{t}=5.403$, $\mathrm{p}=0.000,0.000<.05)$ and persistence $(\mathrm{t}=5.919, \mathrm{p}=0.000,0.000<.05)$. We can also find that there is difference among high-proficient and low-proficient English learners in terms of the monitoring $(\mathrm{t}=2.973, \mathrm{p}=0.005$, $0.005<.05)$ and frustration endurance $(\mathrm{t}=2.895, \mathrm{p}=0.006,0.006<.05)$, which are not as strong as the above dimensions, but no significant difference has been found in the aspect of thinking ability $(\mathrm{t}=-1.231, \mathrm{p}=0.225$, $0.225>.05)$, independence $(\mathrm{t}=1.474, \mathrm{p}=0.148,0.148>.05)$ and innovation $(\mathrm{t}=1.463, \mathrm{p}=0.151,0.151>.05)$. That is to say, the higher level of the English performance, the better performance in psychological quality and its seven dimensions: initiative, self-confidence, responsibility, self-control, methods, persistence, monitoring and frustration endurance. And there is no obvious difference in the three other dimensions: independence, innovation and thinking ability. And the reason behind the results will be analyzed in the following parts:

The first significant result is that there is an apparent difference among high-proficient and low-proficient English learners in terms of the psychological quality $(\mathrm{t}=6.131, \mathrm{p}=0.000,0.000<.05)$, initiative $(\mathrm{t}=5.065, \mathrm{p}=0.000$, $0.000<.05)$, self-confidence $(\mathrm{t}=4.496, \mathrm{p}=0.000,0.000<.05)$, responsibility $(\mathrm{t}=5.456, \mathrm{p}=0.000,0.000<.05)$, self-control $(\mathrm{t}=4.386, \mathrm{p}=0.000,0.000<.05)$, methods $(\mathrm{t}=5.403, \mathrm{p}=0.000,0.000<.05)$ and persistence $(\mathrm{t}=5.919$, $\mathrm{p}=0.000,0.000<.05)$.

As for the initiative, initiative is a vigorous state of mind that is not satisfied with the present situation and unswervingly pursues the new goals. The students who have high initiative will be more diligent than the low initiative students for the reason that they are always not satisfied with their learning achievements at present and want to make more progress.

Self-confidence plays a significant role in our daily life, especially in learning. As long as you believe yourself, you won't give up easily and you will hold the belief that you can really achieve it no matter what happened. Therefore, the students who are more confident will behave better in English learning than the students who are lack of confidence.

The sense of responsibility in study shows that the class attends the class earnestly, completes the homework on time, is the performance which is responsible for their own study. The responsible student in order to live up to the parents and teachers' expectations, will go to study harder. By contrast, the students with weak sense of responsibility present a kind of indifferent attitude. Therefore, the students who have a strong sense of responsibility are more likely to get good grades.

Self-control means that you can consciously control on your emotions and behavior, which means a lot to senior high school students. What is known to us is that high school students are in a special period and their willpower is too weak to resist the temptation of the outside world, such as the temptation from the computer games. Under the impact of the computer games and other temptation, they often skip school or fail to finish their homework on time, which will seriously affect their English performance. Thus, the students who can better control themselves will be more likely to resist the temptation and still work hard.

Methods refers to learning strategies. In English learning, we often find that some students study very carefully but cannot always achieve good results.

English learning, diligence is the basis, Learning strategies are also important. A good learning strategy can help students learn effectively and make greater progress in a relatively short period of time. Students with good learning methods know how to recite words effectively. They can use scientific knowledge to help themselves to learn English. The students who are weak in method will get half the result. Therefore, the method is closely related to English learning.

Last but not the least, persistence, no wonder, is found that there exists the correlation with English performance. Persistence means that a person persists to pursue one thing until it achieves. If you insist on one thing, you will 
achieve it one day, so does the learning English. As for the English instructors, we should try to foster their sense of persistence and help them hold the belief that as long as they strive, they will get the success.

The second meaningful founding is that there is difference among high-proficient and low-proficient English learners in terms of the monitoring $(\mathrm{t}=2.973, \mathrm{p}=0.005,0.005<.05)$ and frustration endurance $(\mathrm{t}=2.895, \mathrm{p}=0.006$, $0.006<.05)$, which are not as strong as the above dimensions.

In terms of thinking ability $(\mathrm{t}=-1.231, \mathrm{p}=0.225,0.225>.05)$, independence $(\mathrm{t}=1.474, \mathrm{p}=0.148,0.148>.05)$ and innovation $(\mathrm{t}=1.463, \mathrm{p}=0.151,0.151>.05)$, there are no obvious difference between high-proficient and low proficient.

\section{Conclusions}

In terms of the major results of the present study, some practical and useful pedagogical implications for English teachers and students could be listed and summarized. From the perspective of the English teachers, they are supposed to not only strive to enhance the grades of the students but also pay more attention to the psychological quality of the students. With a better psychological quality in English learning, students are more likely to get good grades. From the results of the data, we can find that persistence; methods; self-confidence; responsibility; initiative; self-control are strongly related to English achievement, therefore, in developing students' psychological quality, our teachers should focus on these areas. In order to improve the persistence of students' English learning, our English educators can give rewards to students who insist on reciting words and notes carefully for one month. When the students persist for a month, we should guide the students to pay attention to the progress of their English performance after insisting on learning, and lead the students to find that the students who insist on learning English can improve their English performance so that they want to learn English from the heart, not just to get the prize. We first cultivate the external motivation of the students by reward, and then change the external motivation of the students into a more persistent intrinsic motivation through the proper guidance of the teachers at the appropriate time. As for the methods, we can guide students to recite words by using English phonetic alphabet and pictographic memory. In reading class, we should guide students to learn skimming, sacnning and intensive reading strategies as far as possible. In terms of self-confidence, we can affirm our students' small progress and help them build up confidence in learning English. In developing students' initiative, our English teachers should help students develop interest in learning English. Only when students are interested in English can they learn English conscientiously. Thus, our English class should not only cultivate students' knowledge and skills goals, but also focus on the students' emotional goals and cultivate their interests in English learning. Thereore, we should continually polish our teaching skills and manage to provide students with a more vivid class. Besides, we can also find that independence, (frustration endurance) resilience and monitoring are positively related to English achievement. This shows that we English educators can not ignore these elements in the training of students. In the ordinary English teaching, we should cultivate the students' ability to think independently and at the same time help them to foster their own critical thinking, not to give students an answer too quickly, and should give students the space to think about to cultivate the independence of the students. In terms of frustration endurance, we should guide students to attribute correctly when they failed in order to keep the students' enthusiasm for learning and encourage them to continue their efforts. We are a new generation of English teachers, there should be more scientific ways to improve students' English performance. We should get out of the old circle. With a new way of thinking about students' scores, a new perspective to help students improve their English.

\section{Reference}

Adlina, A. S., \& Atika, E \& Hamid R. F. (2012). Motivation and Language Proficiency: Instrumental and Integrative Aspects.Social and Behavioral Science, 66, 423-440.

Atkinson, J. M., Clark, R. A., \& Lowell, E. L. (1953). The Achievement Motive. New York: Appleton.

Brookover, W. B., Thomas, S., \& Paterson, A. (1964). Self-concept of ability and school achievement. Sociology of Education, 37(3), 271-278. https://doi.org/10.2307/2111958

Bailey, P. (2000). Using Learning Style to Predict Foreign Language Achievement at the College level. System, 28, 115-133. https://doi.org/10.1016/S0346-251X(99)00064-0

Baumeister, R. F., \& Campbell, J. D., Krueger, J. I., \& Vohs, K. D. (2003). Does high self-esteem cause better performance, interpersonal success happiness, or healthier lifestyles? Psychological science in the public interest, 4(1), 1-44. https://doi.org/10.1111/1529-1006.01431

Chapelle, C. A. (1983). The relationship between ambiguity tolerance and success in acquiring second language in adult learners. $\mathrm{PhD}$ thesis, University of Illions. 
Child, D. (1981). Psychology and the Teacher. Lodon: Holt, Rinehart \& Winston.

Cohen, Y., \& Norst, M. J. (1989). Fear, dependence and loss of self-esteem: affective barriers in second language learning among adults. Relc Journal, 20(2), 61-77. https://doi.org/10.1177/003368828902000206

Dornyei, Z. (1998). Motivation in Second Language and Foreign Language Learning. Language Teaching, 31(03), 117-135. https://doi.org/10.1017/S026144480001315X

Elliot, A. J., \& McGregor, H. (1988). Achievement goals, study strategies, and exam performance: Amediational analysis, Journal of Educational Psychology, 90(1), 213-216.

Ellis, R. (1994). The Study of Second Language Acquisition (pp. 199-200, 228, 515-517). Oxford University Press.

Gardner, R. C., \& Lambert, W. E. (1972). Attitudes and Motivation in Second Language. Rowley Mass: Newbury House.

Gardner, R. C., Lalonde, R. N., \& Moorcroft, R. (2002). The role of Attitude and Motivation in Second Language Learning: Correlational and Experimental Considerations. Language Learning, 35(2), 210-226.

Govaerts S., \& Gregoire J. (2008). Development and Construct Validation of an Academic Emotions Scale. International Journal of Testing, 2(1), 34-54. https://doi.org/10.1080/15305050701808649

Harris, S. L. (2009). The Relationship Between Self-Esteem and Academic Engineering Program at a Research Extensive University in the Southern University. The United States. $\mathrm{PhD}$ thesis, Louisiana State.

Keith, T. J. (1988). Path analysis: An introduction for school psychologists. School Psychological Review.

Oxford, R. L. (1990). Language Learning Strategies: what every teacher should know. New York: Newbury House.

Rubio, F. (2007). Self-esteem and, foreign language learning. UK, Newcastle: Cambridge Scholars Publishing.

Pintrich, P. R. (2000). An achievement goat theory perspective on issues in motivation terminology, theory and research. Contemporary Educational Psychology, 25, 92-104. https://doi.org/10.1006/ceps.1999.1017

Rafael, K. (1990). Cognitive Event-Related Potentials in Attention Deficit Disorder. Journal of Learning Disabilities.

Zimmerman, B. J., \& Martinez-Pons, M. (1986). Development of a structured interview for assessing student use of self-regulated learning strategies. Journal of American Educational Research, 23, 614-628. https://doi.org/10.3102/00028312023004614

\section{Copyrights}

Copyright for this article is retained by the author(s), with first publication rights granted to the journal.

This is an open-access article distributed under the terms and conditions of the Creative Commons Attribution license (http://creativecommons.org/licenses/by/4.0/). 